\title{
HUBUNGAN PENGEMBANGAN WISATA DENGAN STRATEGI \\ NAFKAH DAN TARAF HIDUP RUMAH TANGGA NELAYAN DESA KARIMUNJAWA
}

\section{(The Correlation of Tourism Development with Livelihood Strategies and Living Standard of Fisherman Household in Karimunjawa Village)}

\author{
Luki Setyawan $^{1)}$ dan Arif Satria ${ }^{1)}$ \\ ${ }^{1)}$ Departemen Sains Komunikasi dan Pengembangan Masyarakat, Fakultas Ekologi \\ Manusia, Institut Pertanian Bogor, Darmaga Bogor 16680, Indonesia \\ Email:luki.setyawan@gmail.com; arifsatria@apps.ipb.ac.id
}

\begin{abstract}
The purpose of this study to analyze the correlation of tourism development with livelihood strategies and living standard of fisherman household of Karimunjawa Village. Type of attraction that developed in Indonesia is ecotourism and tourism. Tourism development are good not only focus on the balance of nature and level of the economy, but also the welfare of local communities. Fisherman are part of the local community in the implementation of coastal tourism and small islands. This study will analyze about tourism and fisher household. This research combined quantitative approach using questioner method and qualitative approach using interview method. The result of this study explained about the development of tourism had affected the livelihood strategy of fisherman household. Implementation of the strategy is not only living as part of efforts to sustain life, but also improve the standard of living of fishermen household.
\end{abstract}

Keywords: ecotourism, national park, livelihood structure

\begin{abstract}
ABSTRAK
Penelitian dilaksanakan di Kabupaten Lombok Tengah, Nusa Tenggara Barat, yang mencakup dua dusun, yaitu Dusun Sade, Desa Rembitan, Kecamatan Jonggata dan Dusun Ketangge, Desa Sukarara, Kecamatan Pujut. Tujuan penelitian adalah untuk melihat struktur nafkah dan bentuk strategi nafkah rumahtangga penenun. Penelitian ini juga menganalisis pengaruh pemanfaatan lima modal nafkah terhadap resiliensi rumahtangga penenun. Penelitian ini menggunakan metode kuantitatif yang didukung dengan data kualitatif. Metode kuantitatif dilakukan melalui pendekatan survei dan menggunakan kuesioner. Pengumpulan data kualitatif dilakukan dengan menggunakan wawancara mendalam. Pendekatan lain yang digunakan adalah melalui observasi lapang di lokasi penelitian. Hasil penelitian menunjukkan bahwa terdapat pengaruh antara modal nafkah terhadap tingkat resiliensi, serta memaparkan faktor-faktor yang mempengaruhi tingkat resiliensi rumahtangga penenun di dua dusun. Faktor yang mempengaruhi tingkat resiliensi di Dusun Sade yaitu pinjaman, tingkat alokasi tenaga kerja dan penguasaan keterampilan. Sedangkan faktor-faktor yang mempengaruhi tingkat resiliensi rumahtangga penenun di Dusun Ketangge yaitu pinjaman, tingkat lama waktu bersekolah dan tingkat investasi barang.
\end{abstract}

Kata kunci: ekowisata, taman nasional, struktur nafkah 


\section{PENDAHULUAN}

Pariwisata merupakan perpindahan atau perjalanan secara temporer dari tempat mereka biasanya bekerja dan menetap ke tempat luar, guna mendapatkan kenikmatan dalam perjalanan atau di tempat tujuan (Mathieson dan Wall 1982). Pariwisata ini bersifat mass tourism, artinya pariwisata tidak mengenal batasan daya dukung. Permintaan akan selalu dipenuhi. Pariwisata telah menjadi salah satu industri besar dunia. Negara dan teritori seperti Thailand, Filipina, Singapura, Hawaii, Galapagos, Tonga dan kepulauan Karibia menjadikan pariwisata sebagai andalan sumber devisanya. Di kepulauan Karibia, pariwisata menyumbang penerimaan sampai US\$ 18,7 miliar tahun 2011 (Duval 2004 dalam Pitana dan Gayatri 2005).

Di Indonesia, kunjungan wisatawan tiap tahun terus meningkat. Data BPS mencatat, dalam kurun waktu 2010-2013, kunjungan wisatawan meningkat tiap tahun dari 7.002.944 orang pada tahun 2010 menjadi 8.802.129 orang pada tahun 2013. Negara dengan jumlah wisatawan terbanyak datang dari Amerika Serikat dengan total 831.621 orang dari kurun waktu 2010-2013. Peningkatan jumlah kunjungan wisatawan meningkatkan penerimaan negara dari sektor devisa. Pada tahun 2010, jumlah devisa dari wisatawan mancanegara mencapai $7.603,45$ juta dollar AS. Penerimaan ini terus meningkat setiap tahun dengan jumlah berturutturut 8.554,39 juta dollar AS (2011), 9120,89 juta dollar AS (2012) dan mencapai 10.054,15 juta dollar AS pada tahun 2013 (BPS 2014).

Selain meningkatkan penerimaan devisa, permintaan wisata yang terus naik membawa efek samping berupa kerusakan lingkungan. Konsep wisata umum (pariwisata) tidak memperhatikan keberlanjutan lingkungan, terutama wisata dengan destinasi alami. Sumber daya perairan merupakan salah satu sumber daya yang memiliki daya tarik (attractiveness) pariwisata tinggi. Keberagaman ekosistemnya menyediakan obyek yang menarik bagi wisatawan. Terumbu karang, padang lamun, mangrove, dan wisata pantai merupakan daya tarik utama pariwisata sektor pesisir dan kelautan. Pariwisata berbasis alam (nature) semakin lama akan semakin mengurangi nilai sumber daya itu sendiri. Padahal, meskipun dapat diperbaharui, sumber daya bersifat terbatas. Jika pemanfaatan melebihi daya dukung, sumber daya tersebut tidak dapat pulih dan akhirnya rusak. Adanya keterbatasan sumberdaya serta permintaan pariwisata yang semakin tinggi akhirnya membuahkan konsep wisata baru berwawasan lingkungan, yaitu ekowisata (ecotourism).

Ekowisata pertama kali diperkenalkan pada tahun 1990 oleh organisasi The Ecotourism Society. Menurut The Ecotourism Society, ekowisata adalah suatu bentuk perjalanan wisata ke daerah alami dengan tujuan mengkonservasi lingkungan dan melestarikan kehidupan dan kesejahteraan penduduk setempat. Yulianda (2007) memberikan gambaran lebih praktis, ekowisata merupakan bentuk wisata yang dikelola dengan pendekatan konservasi. Salah satu ekowisata di Provinsi Jawa Tengah dapat ditemukan dalam kawasan Taman Nasional Karimunjawa (TN Karimunjawa). Ekowisata yang dibangun di TN Karimunjawa adalah ekowisata yang memanfaatkan potensi alam dan keadaan sosial. Potensi alam yang dikenal di Karimunjawa adalah potensi wisata bahari. selain itu, terdapat potensi wisata lain seperti wisata religi dan wisata budaya.

Desa Karimunjawa merupakan salah satu desa dengan jumlah penduduk paling banyak di daerah TN Karimunjawa. Menurut data sensus penduduk, Desa Karimunjawa dihuni oleh 2736 penduduk dengan perbandingan 1372 laki-laki dan 1356 perempuan. Dari jumlah tersebut, 475 orang (21,39\%) bekerja sebagai nelayan (BTNKJ 2012). Desa Karimunjawa memiliki jumlah nelayan yang cukup tinggi karena wilayahnya sebagian besar pesisir. Nelayan sangat bergantung pada sumber daya alam di sekitarnya, dalam hal ini, pesisir (Satria 2002).

Nelayan didefinisikan sebagai orang yang mata pencahariannya melakukan penangkapan ikan (UU Perikanan No. 45 th 2009). Kegiatan ekowisata memiliki dampak yang signifikan terhadap nelayan. Pengembangan wilayah serta kegiatan ekowisata memengaruhi perekonomian nelayan. Nelayan memegang peranan penting dalam rangka pelaksanaan wisata berbasis lingkungan yang berkelanjutan (Ekowisata) di TN Karimunjawa. Hal ini dikarenakan hubungan mereka yang begitu dekat dengan alam. Berkaitan dengan pengembangan ekowisata, penting untuk dianalisis hubungan dari pengembangan ekowisata tersebut dengan strategi nafkah dan taraf hidup rumah tangga nelayan di Desa Karimunjawa.

Tujuan penelitian dirumuskan sebagai berikut: 
1. Mengidentifikasi pengembangan wisata yang ada di TN Karimunjawa;

2. Menganalisis karakteristik nelayan di Desa Karimunjawa;

3. Menganalisis hubungan pengembangan wisata dengan strategi nafkah rumah tangga nelayan;

4. Menganalisis hubungan karakteristik nelayan dengan strategi nafkah rumah tangga nelayan; dan

5. Menganalisis hubungan strategi nafkah rumah tangga nelayan dengan taraf hidup rumah tangga nelayan.

\section{PENDEKATAN TEORITIS}

\section{Konsep Ekowisata}

Ekowisata merupakan turunan dari pariwisata. Pariwisata diartikan sebagai perpindahan atau perjalanan secara temporer dari tempat mereka biasanya bekerja dan menetap ke tempat luar, guna mendapatkan kenikmatan dalam perjalanan atau di tempat tujuan (Mathieson dan Wall 1982). Perbedaan antara pariwisata (mass tourism) dengan ekowisata (ecotourism) terletak pada batasan yang diterapkan kepada pengunjung. Ekowisata merupakan jenis wisata yang memperhatikan keberlanjutan lingkungan. Munculnya konsep ekowisata dilatarbelakangi oleh degradasi lingkungan yang berlangsung sangat cepat. Dalam kegiatan wisata, terjadi pengurangan nilai sumber daya, baik secara ekonomis maupun ekologis.

Berdasarkan definisi yang diungkapkan para ahli, ekowisata memiliki empat prinsip utama. Pertama, ekowisata merupakan jenis wisata baru yang menjadikan alam sebagai daya tarik (attractiveness) utamanya. Pengunjung yang melakukan perjalanan harus memiliki tanggung jawab dalam kelestarian alam. Kedua, ekowisata harus menerapkan prinsip keberlanjutan. Artinya, permintaan wisata tidak boleh melebihi daya tampung obyek wisata itu sendiri (carrying capacity). Ketiga, ekowisata merupakan wisata yang berorientasi pada peningkatan perekonomian. Ekowisata tidak hanya fokus pada keberlanjutan lingkungan, tapi juga bagaimana lingkungan memberikan jasa yang dapat mendatangkan keuntungan, baik secara langsung maupun tidak langsung. Dalam konteks ini, ekowisata menjadi industri baru dalam meningkatkan jumlah pendapatan. Keempat, ekowisata merupakan jenis wisata yang memasukan kesejahteraan masyarakat sebagai tujuannya. Artinya, ekowisata ikut menjaga eksistensi manusia di sekitar wilayahnya. Secara garis besar, dapat disimpulkan bahwa ekowisata merupakan jenis ekowisata baru yang berbasis pada alam, mengutamakan prinsip keberlanjutan, meningkatkan perekonomian daerah kesejahteraan masyarakat sekitar kawasan.

\section{Konsep Pengembangan Ekowisata}

Pariwisata kini menjadi industri jasa menjanjikan. Pertumbuhan yang berimbang bagi aktivitas perekonomian terjadi akibat majunya pertumbuhan industri pariwisata yang dikembangkan dengan baik (Yoeti 2000). Industri jasa pariwisata menjadi motor bisnis bagi industri jasa lain seperti perhotelan, agen perjalanan, dan industri kerajinan (Yoeti 2000).

Untuk mewujudkan industri pariwisata yang berdaya saing, strategi pengembangan ekowisata sangat diperlukan. Strategi pengembangan ekowisata ini didasarkan dari permintaan dan penawaran jasa wisata. Strategi pengembangan ekowisata sangat beragam berdasarkan analisis sumber dan tujuan pengembangan. Setyadi et al (2012) memakai framework ANP yang meliputi lima cluster untuk mengukur kesiapan suatu kawasan ekowisata. Kelima cluster tersebut adalah tujuan, aspek, masalah, solusi, dan strategi pengembangan. Temuan Setyadi et al (2012) untuk mengembangkan ekowisata di Yepen, diantaranya:

1. Peningkatan kerjasama dan pemahaman terhadap ekowisata bagi stakeholder;

2. Peningkatan komitmen dan dukungan dari pemerintah/pemerintah daerah;

3. Penegakan hukum, aturan/tata tertib, dan sanksi yang tegas dan konsisten;

4. Peningkatan kuantitas dan kualitas produk ekowisata melalui inovasi dan diversifikasi serta pemeliharaan;

5. Pembangunan sarana inrastruktur, sarana transportasi dan aksesbilitas;

6. Peningkatan kesadaran masyarakat terhadap lingkungan; dan

7. Penggalangan dana untuk konservasi.

\section{Karakteristik Sosial-Ekonomi Nelayan}

Berdasarkan nelayan dapat digolongkan menjadi empat (Polnac 1998 dalam Amanah dan Utami 2006): Nelayan tradisional yang bersifat subsisten, nelayan yang menggunakan teknologi penangkapan maju, nelayan komersial, dan nelayan industri. Nelayan tradisional umumnya termasuk nelayan 
kecil, dimana kepemilikan modalnya terbatas dan sulit mengakses layanan publik (Amanah dan Utami 2006). Dalam persaingan hak penggunaan sumber daya, nelayan selalu berada dalam posisi kalah (the loser) (Winson 1992 dalam Kinseng 2011). Hal ini akan memicu konflik, baik konflik penggunaan sumber daya maupun penggunaan teknologi untuk mengakses sumber daya (Sobari et al, 2003). Persaingan-persaingan ini dijelaskan dalam tipologi konflik dikalangan nelayan (Charles 1992 dan 2001 dalam Kinseng 2011).

Nelayan di Indonesia sebagian besar di golongkan miskin (Kusnadi 2009), identik dengan keterbatasan akses sumber daya maupun fasilitas. Keterbatasan ini yang akan memunculkan konflik, baik konflik kelas maupun konflik agraria (Satria 2002 dalam Kinseng 2011).

Terkait dengan perubahan ekologis, nelayan akan melakukan strategi adaptasi supaya dapat tetap bertahan dan eksis di lingkungan tersebut (Helmi dan Satria 2012). Strategi adaptasi mutlak diperlukan karena ketergantungan nelayan yang sangat tinggi pada alam. Perubahan-perubahan ekologis terkait pengembangan ekowisata ini akan turut mengubah pola-pola sosial dan ekonomi nelayan.

\section{Strategi Nafkah Nelayan}

Secara umum, strategi nafkah merupakan taktik dan aksi yang dibangun oleh individu atau kelompok untuk mempertahankan kehidupan mereka dengan tetap memperhatikan eksistensi infrastruktur sosial, struktur sosial, dan sistem nilai budaya yang berlaku (Dharmawan 2007). Ellis (2000) menjelaskan strategi nafkah sebagai livelihood asset, yaitu:

1. Modal Sumber Daya Alam (Natural Capital), yaitu modal lingkungan, merupakan gabungan dari berbagai faktor biotik dan abiotik di sekeliling manusia. Modal ini dapat berupa sumber daya yang dapat diperbarui dan tidak dapat diperbarui;

2. Modal Fisik (Physical Capital), yaitu modal berbentuk infrastruktur dasar seperti saluran irigasi, jalan, gedung, dan lain sebagainya;

3. Modal Manusia, yaitu modal berupa tenaga kerja yang tersedia dalam rumahtangga yang dipengaruhi oleh pendidikan, keterampilan, dan kesehatan untuk dapat memenuhi kebutuhan hidupnya;

4. Modal Finansial (Financial Capital), yaitu modal berupa uang yang digunakan oleh suatu rumahtangga. Modal ini dapat berupa uang tunai, tabungan, ataupun akses dan pinjaman; dan

5. Modal Sosial (Social Capital), yaitu gabungan komunitas yang dapat memberikan keuntungan bagi individu atau rumahtangga yang tergabung di dalamnya. Contoh modal sosial adalah jaringan kerja (networking) yang merupakan hubungan vertikal maupun hubungan horizontal untuk bekerjasama dan memberikan bantuan untuk memperluas akses terhadap kegiatan ekonomi.

Perubahan-perubahan ekologis yang terjadi di kawasan pesisir memengaruhi kehidupan nelayan sehingga nelayan beradaptasi. Bentuk adaptasi nelayan menanggapi perubahan lingkungan dapat beragam, seperti penganekaragaman pendapatan, penganekaragaman alat tangkap, perubahan daerah tangkapan, memanfaatkan hubungan sosial, dan mobilisasi anggota rumah tangga (Helmi dan Satria 2012).

Berdasarkan penelitian-penelitian yang sudah pernah dilakukan oleh peneliti sebelumnya, dapat disimpulkan bahwa strategi nafkah nelayan muncul karena berbagai perubahan, terutama yang diakibatkan oleh berbagai perubahan ekologis ataupun sebagai bentuk adaptasi nelayan. Bentuk strategi nafkah yang dilakukan oleh nelayan dapat dikelompokan kedalam tiga hal, yaitu: pola nafkah ganda, migrasi, optimalisasi tenaga kerja anggota rumah tangga, dan jejaring sosial.

\section{Pengaruh Ekowisata terhadap Ekonomi Nelayan}

Pengelolaan ekowisata yang baik salah satunya dapat dicirikan dengan meningkatnya pendapatan masyarakat lokal. Pengelolaan ekowisata memberi ruang sekaligus dampak ekonomi berantai. Nelayan sebagai bagian masyarakat yang memiliki hubungan paling erat dengan pesisir dan laut yang terkena dampak ekonomi paling banyak. Secara umum, dampak ekonomi yang dirasakan berupa peningkatan pendapatan (positif). Hal ini dikarenakan adanya tambahan sumber mata pencaharian selain dari hasil melaut (strategi nafkah ganda) (Satria 2009). Penurunan pendapatan juga mungkin terjadi karena berkurangnya akses nelayan pada sumber daya alam itu sendiri.

Penelitian Tafalas (2010) di Raja Ampat membuktikan adanya dampak positif dari kegiatan ekowisata terhadap perekonomian nelayan. Meskipun dampaknya belum sampai pada 
perubahan struktur mata pencaharian, adanya kegiatan ekowisata telah memperluas lapangan kerja serta kesempatan berusaha. Peningkatan pendapatan bersumber baik dari kegiatan wisata langsung maupun tidak langsung. Peningkatan pendapatan dari kegiatan wisata langsung dapat dilihat dari penambahan jenis pekerjaan baru sekaligus menambah lapangan kerja baru seperti tour guide. Selain itu, penyediaan home stay bagi wisatawan juga membuka kesempatan peningkatan pendapatan.

\section{Konsep Taraf Hidup}

Kebutuhan hidup atau taraf hidup dapat dijelaskan sebagai kebutuhan yang sangat penting guna kelangsungan hidup manusia, baik yang terdiri dari barang dan jasa seperti konsumsi (makanan, perumahan, pakaian) maupun dalam keperluan sosial tertentu (seperti air minum, sanitasi transportasi, kesehatan dan pendidikan (Esmara 2004). Taraf hidup dibedakan atas taraf hidup primer dan taraf hidup sekunder (Manullang 2011). Taraf hidup primer adalah kebutuhan yang paling utama, yaitu makanan, minuman, pakaian, dan perumahan. Sedangkan taraf hidup sekunder adalah kebutuhan yang diperlukan guna melengkapi kebutuhan utama.

Perubahan-perubahan yang terjadi karena pengembangan ekowisata telah merubah strategi nafkah nelayan. Strategi nafkah ini berguna untuk menyiasati perubahan yang dapat menurunkan perekonomian rumah tangga. Tingkat perekonomian salah satunya dapat diukur dari tingkat pendapatan suatu rumah tangga (Istiqlaliah 2010). Tingkat pendapatan rumah tangga nelayan di kawasan ekowisata dapat diukur dari pendapatan hasil tangkapan ikan dan pendapatan hasil non tangkapan ikan. Pendapatan hasil non tangkapan ikan dapat berupa budidaya, berdagang, dan penyediaan jasa wisata.

\section{KERANGKA PEMIKIRAN}

Perubahan-perubahan akibat pengembangan ekowisata mengakibatkan berbagai dampak yang mengharuskan nelayan untuk beradaptasi dengan perubahan tersebut. Salah satu bentuk adaptasi dari nelayan terkait dengan pengembangan ekowisata ini adalah strategi nafkah nelayan. Strategi nafkah nelayan terkait dengan dampak pengembangan wisata ini dapat dilihat dari tingkat migrasi, pola nafkah ganda, dan optimalisasi tenaga kerja anggota keluarga.
Selain faktor dari pengembangan ekowisata, strategi nafkah nelayan juga dipengaruhi dari karakteristik nelayan tersebut. Waktu kerja, karakteristik usaha sampai pada kelas sosial akan menentukan seperti apa strategi nafkah yang akan diterapkan oleh nelayan. Kombinasi berbagai faktor tersebut akan memengaruhi taraf hidup rumah tangga nelayan di Desa Karimunjawa.

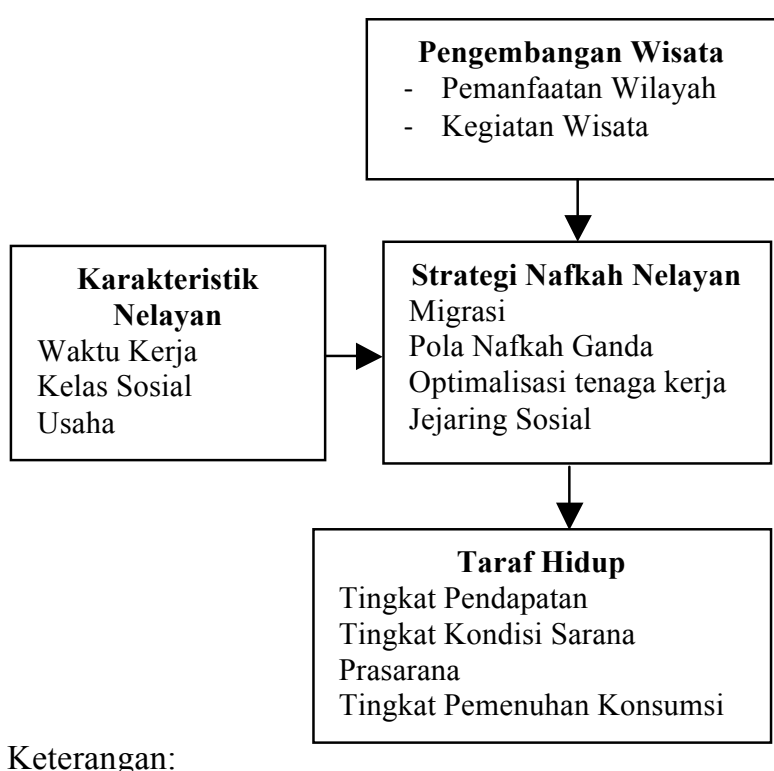

$\longrightarrow$ : Berhubungan

Gambar 1 Kerangka Pemikiran

\section{Hipotesis Penelitian}

Hipotesis penelitian ini yaitu:

1. Diduga pengembangan wisata berhubungan dengan strategi nafkah nelayan Desa Karimunjawa;

2. Diduga karakteristik nelayan memiliki hubungan dengan strategi nafkah rumah tangga nelayan; dan

3. Diduga, strategi nafkah rumah tangga nelayan memiliki hubungan dengan taraf hidup rumah tangga nelayan.

\section{METODE PENELITIAN}

Penelitian ini dilaksanakaan di Desa Karimunjawa, Kecamatan Karimunjawa, Kabupaten Jepara. Lokasi dipilih secara purposive karena lokasi ini termasuk kedalam kawasan konservasi perairan yang menerapkan ekowisata (TN Karimunjawa). Penelitian dilakukan dengan metode kuantitatif yang didukung dengan metode kualitatif. 
Sumber data penelitian adalah informan dan responden. Informan adalah orang yang memberikan informasi tambahan mengenai topik yang terkait dengan penelitian. Responden dipilih secara sengaja. Informan meliputi Dinas Perikanan, Pegawai TN Karimunjawa, HPI, dan tour leader. Responden adalah sumber data utama yang diberikan kuisioner.

Unit analisis penelitian adalah rumah tangga nelayan. Populasi penelitian adalah seluruh nelayan di Karimunjawa. Populasi sampel adalah nelayan dengan kepemilikan kapal di Kampung Kapuran, Desa Karimunjawa. Responden yang dipillih sebanyak 40 rumah tangga dari 81 rumah tangga nelayan. Pemilihan sampel menggunakan teknik sampel acak sederhana (simple random sampling). Metode kualitatif berupa wawancara mendalam dan observasi langsung digunakan untuk mendukung pengumpulan data primer selain dari kuisioner.

Data sekunder diperoleh melalui studi dokumen, data-data, informasi tertulis, maupun literaturliteratur yang berkaitan dengan topik penelitian, seperti jumlah kunjungan wisata, rencana pengembangan ekowisata TN Karimunjawa, dan data-data terkait. Data sekunder dapat diperoleh dari Balai Taman Nasional Karimunjawa, Dinas Budaya dan Pariwisata Kabupaten Jepara, dan sumbersumber data lain yang relevan.

Data kuantitatif diperoleh melalui kuisioner yang sudah diisi oleh responden. Data kemudian disajikan dalam bentuk tabel frekuensi. Sebelumnya, data kuantitatif akan diolah dengan uji korelasi Rank Spearman untuk melihat hubungan antar variabel dengan data berbentuk ordinal. Tingkat kesalahan yang digunakan dalam penelitian ini adalah sebesar 5 persen atau taraf nyata $(\alpha) 0.50$, dengan tingkat kepercayaan 95 persen. Pengolahan data dilakukan menggunakan SPSS 20.0 for Windows dan Microsoft Excell 2007.

Data kualitatif hasil wawancara mendalam dan observasi langsung diolah dan dianalisis dengan cara mereduksi data, menyajikan data, dan menarik kesimpulan dan disampaikan secara deskriptif analitik guna mempertajam hasil penelitian. Tahap terakhir yaitu menarik kesimpulan sesuai dengan rumusan masalah dan tujuan penelitian yang sudah disusun.

\section{PENGEMBANAN WISATA KARIMUNJAWA}

\section{Zona Pemanfaatan Wisata BTNKJ}

Sejarah penetapan Taman Nasional Karimunjawa (TNKJ) dimulai dari penetapan laut Karimunjawa sebagai kawasan Cagar Alam pada tanggal 9 April 1986 melalui SK Menhut NO 123/Kpts-II/1986 seluas 111.625 ha yang meliputi $110.117,30$ ha kawasan perairan dan $1.507,70$ ha kawasan darat. Pada tahun 2001, seluruh kawasan perairan di TN Karimunjawa ditetapkan sebagai kawasan pelestarian alam perairan melalui Keputusan Menteri Kehutanan No.74/Kpts-II/2001.

Pada awal penetapannya, TNKJ dibagi ke dalam 4 zona, yaitu zona inti, zona perlindungan, zona pemanfaatan dan terakkhir zona penyangga (SK Dirjen PHKA No127/Kpts/DJVI/1989). Penetapan zonasi mengalami perubahan pada tahun 2005 dan terakhir pada tahun 2012. Pembagian zonasi tahun 2012 meliputi zona inti, zona rimba, zona perlindungan bahari, zona pemanfaatan darat, zona pemanfaatan wisata bahari, zona budidaya bahari, dan zona religi.

Wilayah laut TNKJ mencapai 110.117,30 ha. Wilayah laut TNKJ dibagi lagi menjadi zona perlindungan bahari $(2.599,77$ ha), zona pemanfaatan wisata bahari $(2.733,73$ ha), dan zona budidaya bahari $(1.370,73$ ha). Terdapat 2 perbedaan utama antara zonasi tahun 2005 dan 2012, yaitu perubahan besaran wilayah yang dijadikan zonasi pemanfaatan wisata dan perubahan nama dari zona pemanfaatan pariwisata menjadi zona pemanfaatan wisata bahari.

\section{Persepsi terhadap TN Karimunjawa}

Selain peran utamanya sebagai institusi khusus pengelola alam, TN Karimunjawa memegang peranan penting dalam upaya promosi wisata bahari dan darat Karimunjawa. Meskipun peranan pentingnya diakui oleh banyak masyarakat, tidak sedikit juga yang menentang kehadiran TN Karimunjawa. Hal ini dikarenakan terdapat beberapa peraturan yang dari Taman Nasional yang tidak sesuai dengan keinginan warga, salah satunya adalah penerapan tiket masuk kawasan Taman Nasional Karimunjawa.

Menurut penuturan kepala seksi II TN Karimunjawa, sekitar bulan November-Desember 2014 terjadi konflik antara Balai Taman Nasional Karimunjawa dengan masyarakat setempat. Konflik 
ini dilatarbelakangi oleh penerapan tiket masuk kawasan bagi pengunjung. Pengunjung lokal dikenai tarif $\mathrm{Rp}$ 15.000,00 sedangkan wisatawan asing harus membayar Rp 150.000,00. Penerapan tarif ini dikhawatirkan masyarakat akan menurunkan kunjungan wisatawan ke Karimunjawa. Nelayan menganggap BTN Karimunjawa menghambat dan bahkan menghalangi bisnis wisata mereka, seperti diungkapkan oleh ADY.

“...mas, BTN ki sok-sok berkuasa. Laut

kui ora mereka seng nggawe si mas, kok mereka sak enake dewe narik tiket. Duit tiket juga ora jelas dinggo opo. (ADY, nelayan, tour leader)

\section{“...Mas, BTN ini sok berkuasa. Laut bukan mereka yang buat mas, kok mereka seenaknya sendiri mungut tiket. Uang tiket juga tidak jelas dipakai untuk apa. (ADY, nelayan, tour leader)}

\section{Wisata sebagai Industri}

Wisata di Karimunjawa mengalami tren peningkatan jumlah pengunjung dari tahun ke tahun. Sempat terjadi penurunan pengunjung pada tahun 2012. Akan tetapi, penurunan ini disebabkan oleh perubahan aturan zonasi yang baru saja ditetapkan. Tren pengunjung Karimunjawa dapat dilihat pada Gambar 2.

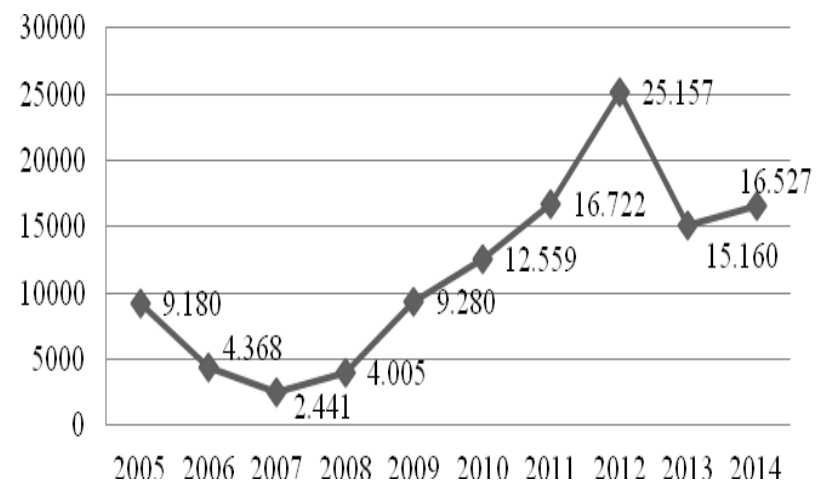

Gambar 2 Jumlah pengunjung tahun 2004-2014

Gejala wisata sebagai industri bertentangan dengan 3 prinsip ekowisata. Pertama, pilar keberlanjutan lingkungan. Menurut penelitian yang dilakukan oleh Balai Taman Nasional Karimunjawa (BTNKJ) dan World Conservation Society (WCS) pada tahun 2011, kunjungan wisatawan memberikan dampak terhadap kebersihan lingkungan. Setidaknya, ratarata 10 persen terumbu karang mengalami kerusakan patah dan bagian lain menghasilkan pertumbuhan alga yang meningkat dan hilangnya jaringan pada karang.

Kedua, pilar ekonomi. Pilar ekonomi dari keberadaan ekowisata adalah adanya sumbangan dana dari penyelenggaraan wisata kedalam kas negara. Pemasukan sektor ini dapat dilihat dari Penerimaan Negara Bukan Pajak (PNBP). Pada tahun 2014, BTNKJ menerima pendapatan sampai Rp 87.097.500,-. Jumlah tersebut berasal dari sumbangan 9 obyek pungutan yang dilakukan di Balai TN Karimunjawa. Secara khusus, total sumbangan aktivitas wisata bagi penerimaan PNBP adalah Rp 56.247.500,-. Grafik penerimaan PNBP dari sektor wisata dapat dilihat pada Gambar 3.

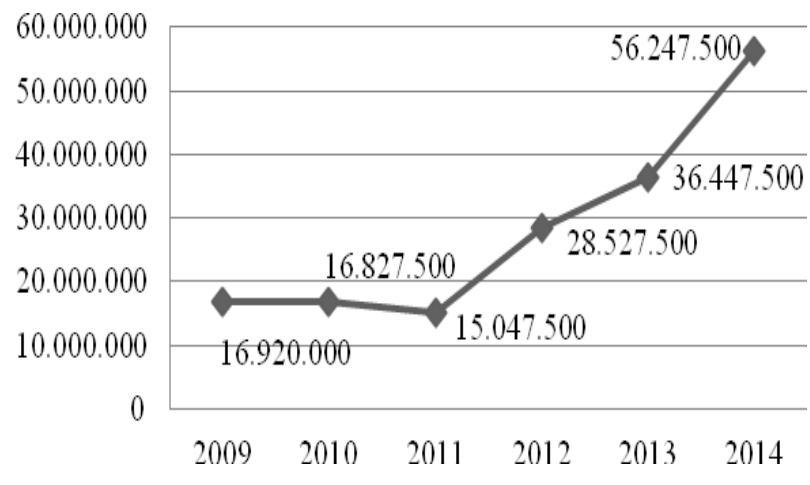

Gambar 3 Penerimaan PNBP sektor wisata (20092014)

Ketiga, pilar sosial-budaya masyarakat. Terkait dengan adat istiadat setempat, wisata membawa dampak negatif terhadap pergaulan remaja. Cara berpakaian wisatawan yang cenderung minimalis banyak ditiru oleh remaja. Hal ini tidak sesuai dengan prinsip ekowisata yang mempertahankan kekhasan budaya masyarakat setempat. Efek negatif tersebut ditegaskan oleh MSN.

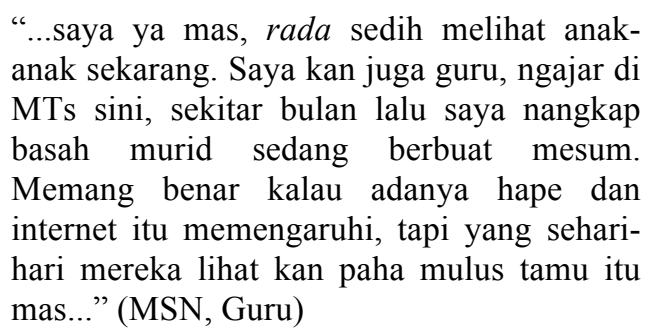

Berdasarkan ketiga prinsip tersebut, wisata Karimunjawa tidak dapat lagi diolongan ke dalam ekowisata, tapi sudah menjadi pariwisata (mass tourism). 


\section{Pengembangan Wilayah}

Pengembangan wilayah pada dasarnya diatur oleh Balai TN Karimunjawa sebagai pemegang otoritas TN Karimunjawa. Pengembangan wisata Karimunjawa diawali dengan penetapan ruang wisata alam. Penetapan ruang wisata ini dinamai zona pemanfaatan. Zona pemanfaatan TN Karimunjawa dibagi menjadi dua, yaitu ruang wisata alam intensif, meliputi Pulau utama (Kemujan dan Karimunjawa) dan ruang wisata alam terbatas, meliputi pulau-pulau kecil.

Pemanfaatan ruang wisata bahari untuk kegiatan wisata di Desa Karimunjawa dipisahkan menjadi tiga, yaitu: pemanfaatan daerah pantai, pemanfaatan daerah upwelling/perbatasan antara pantai dengan laut terbuka, dan pemanfaatan laut terbuka. Sebanyak 65 persen masyarakat setempat sudah memahami tentang pengembangan wilayah ini. Pemahaman masyarakat setempat mengenai pengembangan wilayah untuk kegiatan wisata sangat penting karena masyarakat setempat menjadi subyek utama penyedia jasa wisata di Desa Karimunjawa. Konsep pengembangan wisata alam TN Karimunjawa diarahkan pada pengembangan produk interpretasi wisata bawah air, yaitu: (1) The First Step to the Real Reefs, (2) The Exploration of the Uderwater Beauty and Richness of Karimunjawa,dan (3) The Other-side of Karimunjawa.

Penyelenggaraan kegiatan wisata di Desa Karimunjawa terdiri dari tur wisata darat dan tur wisata bahari. Kegiatan wisata yang tersedia di tur darat adalah: (1) Sunset seeing (bukit Joko Tuo) dan (2) Wisata budaya. Sedangkan kegiatan wisata yang tersedia di tur wisata bahari adalah: (1) Menyelam, (2) Snorkleing, (3) Memancing, (4) Berjemur di Pantai, (5) Melihat akuarium laut, (6) Sunset seeing, dan (7) Berkunjung ke pulau tetangga.

Sebanyak 97,5 persen masyarakat memahami dan mengetahui tingginya peluang penyelenggaraan kegiatan wisata di Desa Karimunjawa. Tingginya tingkat pengetahuan masyarakat ini memengaruhi keputusan nelayan memilih pekerjaan tambahan. Buktinya, 62,5 persen nelayan Desa Karimunjawa memilih nelayan wisata sebagai pekerjaan tambahan. Efek berikutnya adalah adanya perpindahan pekerjaan utama dari nelayan tangkap menjadi nelayan wisata.

Destinasi wisata unggulan di Desa Karimunjawa adalah: Pulau (P) Menjangan Besar, P. Menjangan
Kecil, P. Cemara Kecil, P. Cemara Besar, P. Tengah, P. Cilik, Pantai Ujung Gelam, Pantai Nyamplung Ragas, Dermaga Timur, dan Bukit Joko Tuo. Fasilitas pendukung wisata antara lain; listrik, air bersih, jaringan komunikasi, penginapan, pusat cinderamata, dan perbangkan. Pengembangan wisata Karimunjawa memiliki beberapa tantangan, diantaranya isu lingkungan, isu budaya, isu sosial, dan kerjasama antar stakeholder.

\section{KARAKTERISTIK NELAYAN KARIMUNJAWA}

\section{Waktu Kerja}

Karaktersitik nelayan dapat diidentifikasi melalui curahan waktu kerjanya. Kegiatan wisata memicu nelayan untuk mengambil pekerjaan lain, atau bahkan merubah pekerjaan utamanya sebagai nelayan tangkap menjadi nelayan wisata. Menurut Ditjenkan (1999), nelayan dapat dibedakan menjadi 3 jenis berdasarkan curahan waktu kerjanya, yaitu Nelayan Penuh, Nelayan Sambilan Utama, Nelayan Sambilan Tambahan.

Nelayan penuh merupakan nelayan yang seluruh waktu kerjanya digunakan untuk melakukan operasi penangkapan ikan/hewan air/tanaman air lainnya. Nelayan sambilan utama merupakan nelayan yang sebagian besar waktu kerjanya digunakan untuk melakukan operasi penangkapan ikan/hewan air lainnya/tanaman air namun memiliki pekerjaan lain. Sedangkan nelayan sambilan tambahan adalah nelayan yang sebagian kecil waktu kerjanya digunakan untuk melakukan operasi penangkapan ikan/hewan air lainnya/tanaman air namun memiliki pekerjaan lain.

Sebanyak 22,5 persen nelayan Karimunjawa masih tergolong nelayan penuh. Separuh $(50 \%)$ nelayan termasuk golongan nelayan sambilan utama. Sisanya merupakan nelayan sambilan tambahan. Berdasarkan data ini, mayoritas nelayan Karimunjawa sudah memiliki profesi tambahan selain nelayan tangkap sebagai pekerjaan utama.

\section{Kelas Sosial}

Kepemilikan alat tangkap dapat menjadi salah satu alat ukur menentukan kelas sosial yang terbentuk, yaitu nelayan juragan dan nelayan buruh. Kelas sosial nelayan dapat ditentukan berdasarkan kepemilikan kapal dan ukuran tonasenya. Berdasarkan kepemilikan kapal, nelayan dapat dibedakan ke dalam 5 kelas berbeda (Kinseng, 2011). Akan tetapi, di Desa Karimunjawa hanya 
dapat ditemukan 3 kelas nelayan berdasarkan kepemilikan kapal, yaitu Nelayan Buruh, Nelayan Mikro, dan Nelayan Kecil.

Sebanyak 45 persen nelayan Karimunjawa merupakan nelayan mikro. Sebanyak 43 persen nelayan Karimunjawa termasuk dalam nelayan kecil. Hanya 12 persen dari nelayan Karimunjawa yang termasuk dalam nelayan buruh. Nelayan buruh adalah nelayan yang tidak memiliki kapal sendiri. Artinya, penangkapan ikan dilakukan dengan ikut kapal orang lain. Nelayan Mikro adalah nelayan yang memiliki kapal dengan ukuran kurang dari 3 GT, sedangkan Nelayan Kecil memiliki kapal dengan ukuran 3 GT - 5 GT.

\section{Usaha}

Menurut Satria (2002), nelayan dapat dibedakan menjadi 4 golongan berdasarkan jenis usahanya, yaitu: nelayan tradisional, nelayan post-tradisional, nelayan komersial, dan nelayan industri. Akan tetapi, di Karimunjawa tidak ditemukan golongan terakhir.

Sebanyak 70 persen nelayan Karimunjawa merupakan nelayan komersial. Artinya, aktivitas penangkapan ikan berorientasi pada peningkatan keuntungan dengan bantuan teknologi yang lebih maju. Hanya 30 persen nelayan Karimunjawa yang termasuk ke dalam golongan nelayan posttradisonal. Tidak ada nelayan yang masih tergolong nelayan tradisional dengan orientasi kegiatan penangkapan ikan hanya untuk memenuhi kebutuhan sendiri dengan alat tangkap tradisional.

\section{STRATEGI NAFKAH NELAYAN}

\section{Struktur Nafkah}

Komposisi pendapatan rumah tangga nelayan dapat dibedakan menjadi tiga sektor, yaitu nelayan tangkap, wisata, dan sektor lain diluar nelayan tangkap dan wisata. Sektor wisata datang dari aktivitas nelayan wisata, meliputi tour guide, nahkoda kapal, dan penyewaan alat snorkeling serta alat selam. Selain itu beberapa anggota rumah tangga nelayan bekerja sebagai pedagang di wilayah-wilayah objek wisata. Bentuk keterlibatan nelayan tertinggi nelayan dalam industri wisata adalah sebagai tour leader. Tour leader bertugas untuk mengkoordinir kegiatan wisata, mulai dari menjaring calon wisatawan sampai eksekusi di lapang. Nelayan yang menjadi tour leader memiliki jaringan yang cukup luas dan mobilitas yang sangat tinggi.
Tabel 1 Jumlah dan presentase jenis pekerjaan nelayan

\begin{tabular}{lccccc}
\hline \multicolumn{5}{c}{ Pekerjaan Utama } \\
\hline Kategori & Tangkap & Wisata & Lainnya & $\begin{array}{c}\text { Tidak } \\
\text { Ada }\end{array}$ & Total \\
\hline Jumlah & 36 & 4 & 0 & 0 & 40 \\
Persentase & $90 \%$ & $10 \%$ & $0 \%$ & $0 \%$ & $100 \%$ \\
\hline \multicolumn{7}{c}{ Pekerjaan Tambahan } \\
\hline Jumlah & 3 & 25 & 3 & 9 & 40 \\
Persentase & $7,5 \%$ & $62,5 \%$ & $7,5 \%$ & $22,5 \%$ & $100 \%$ \\
\hline
\end{tabular}

Sejak meningkatnya intensitas penyediaan jasa wisata 5 tahun lalu, terjadi perubahan pola nafkah nelayan. Sebanyak 10 persen nelayan beralih profesi menjadi nelayan wisata sebagai pekerjaan utama dan nelayan tangkap sebagai pekerjaan sampingan. Sektor wisata menyediakan lapangan pekerjaan baru bagi para nelayan ketika hasil tangkapan tidak memenuhi kebutuhan. Buktinya, sebanyak 62,5 persen nelayan menjadikan nelayan wisata sebagai profesi kedua setelah nelayan tangkap. Hanya 22,5 persen nelayan yang tidak memiliki pekerjaan lain selain nelayan tangkap. Hal ini memberikan penjelasan bahwa wisata menjadi fenomena baru sebagai sumber nafkah bagi nelayan Karimunjawa.

\section{Pola Nafkah Berserak}

Keterbatasan akses baik terhadap modal maupun sumber daya alam serta penguasaan aset yang kecil menyebabkan nelayan sulit keluar dari kemiskinan. Tidak seperti petani yang dapat berbagi kepemilikan tanah, nelayan tidak memiliki aset yang jelas karena laut bersifat open access. Oleh karena itu, demi mempertahankan kehidupannya atau meningkatkan taraf hidupnya, rumah tangga nelayan melirik sektor lain di luar laut. Pemenuhan kebutuhan ini biasanya dikerjakan oleh anggota rumah tangga lain selain dari kepala keluarga sebagai sumber nafkah utama. Biasanya, istri dan anak nelayan ikut serta dalam kegiatan produktif demi memenuhi kebutuhan keluarga. Setidaknya, dapat ditemukan 2 macam serakan strategi nafkah di Desa Karimunjawa, yaitu serakan spasial (migrasi) dan serakan alokasi tenaga kerja.

Sejak kegiatan wisata mengalami pertumbuhan di Desa Karimunjawa, nelayan Karimunjawa kurang berminat melakukan perpindahan (migrasi) ke tempat lain. Hanya 17,5 persen nelayan yang melakukan migrasi penuh. Sebaliknya, sebanyak 
42,5 persen nelayan tidak melakukan migrasi sama sekali. Hal ini karena tersedianya sumber pendapatan lain selain dari aktivitas nelayan tangkap, yaitu wisata. Jika musim atau hasil tangkapan sedang tidak bagus, nelayan beralih menjadi penyedia jasa wisata. Sumber nafkah sudah dirasa cukup sehingga tidak perlu berpindah lokasi. Nelayan yang banyak melakukan pola nafkah serakan spasial biasanya tidak ikut serta dalam kegiatan penyedia jasa wisata.

Sebanyak 47 persen dari rumah tangga nelayan memiliki minimal 2 orang anggota keluarga yang bekerja. Padahal, jumlah anggota keluarga rumah tangga nelayan mayoritas berjumlah minimal 4 orang. Jumlah anggota keluarga yang banyak seharusnya menjadi potensi bagi sumber nafkah rumah tangga. Pengerahan tenaga kerja dapat disesuaikan dengan kemampuan masing-masing. Hampir sama dengan migrasi, jumlah rumah tangga yang melakukan serakan alokasi tenaga kerja secara penuh hanya 15 persen.

Potensi wisata belum dimaksimalkan dengan baik oleh rumah tangga nelayan. Padahal, sektor produktif diluar nelayan tangkap dan nelayan wisata cukup banyak tersedia. Para istri dapat membuka warung makan, menyewakan rumah sebagai homestay, atau membuat cinderamata.

\section{Jejaring Sosial}

Menurut Dharmawan (2007), salah satu modal yang diperlukan untuk menerapkan strategi nafkah adalah modal sosial. Modal sosial yang dapat diamati dari komunitas nelayan Karimunjawa adalah adanya jejaring sosial yang dimiliki. Jejaring sosial dapat diamati melalui pertemanan maupun kekerabatan yang terjalin. Bahkan, jejaring sosial dapat ditemukan dalam ikatan tertentu seperti patronklien.

Sebanyak 90 persen nelayan Karimunjawa memanfaatkan jejaring sosial, baik sebagian maupun penuh sebagai bentuk strategi nafkah. Bentuk jejaring sosial yang dimanfaatkan berupa sharing alat tangkap atau alat produksi, peminjaman modal usaha, pemasaran hasil produksi, serta informasi mengenai peluang terlibat dalam aktivitas wisata.

Dalam kurun waktu 5 tahun terakhir, kepemilikan alat tangkap secara pribadi meningkat drastis. Hal ini dipengaruhi oleh semakin mudahnya akses sumber permodalan, baik dari perbankan maupun dari juragan. Juragan merupakan orang yang memberikan pinjaman uang atau alat tangkap berjangka dengan imbalan hasil tangkapan harus dijual kepada juragan yang bersangkutan. Sisi negatif dari sistem ini adalah nelayan tidak dapat menentukan harga jual sesuai harga pasar karena harga jual ditentukan oleh juragan. Nelayan tidak dapat mengelak karena sudah punya "ikatan" dengan juragan yang sudah berjasa memberikan pinjaman.

Jejaring sosial juga banyak dimanfaatkan oleh nelayan dalam rangka penyelenggaraan aktivitas wisata di Karimunjawa. Sebanyak 75 persen nelayan Karimunjawa mengandalkan jejaring sosial untuk bekerja di sektor nelayan wisata. Jejaring sosial yang dimanfaatkan adalah peluang kerja dari pertemanan dan kekerabatan serta jaringan informasi.

\section{Pola Nafkah Ganda}

Meningkatnya aktivitas penyelenggaraan wisata di Desa Karimunjawa menyediakan potensi sumber alternatif pendapatan lain selain sektor tangkap bagi nelayan. Modal manusia menjadi faktor penting. Keterampilan yang dimiliki nelayan masih terbatas karena tidak didukung pendidikan yang mumpuni. Oleh karena itu, nelayan melakukan perubahan aktivitas dan perubahan alat tangkap sebagai bentuk adaptasi mereka menyiasati peluang sumber nafkah ganda.

Perubahan aktivitas yang paling kentara dari nelayan adalah perubahan dari aktivitas nelayan tangkap menjadi aktivitas nelayan wisata. Aktivitas sebagai nelayan tangkap adalah menangkap ikan di laut pada pagi hari serta pulang pada sore atau malam hari. Aktivitas ini dapat berlaku sebaliknya, berangkat pada malam hari dan pulang pada pagi atau siang hari. Aktivitas menangkap ikan yang dilakukan berupa memancing dan menembak. Kini, setelah kegiatan wisata ada di Desa Karimunjawa, aktivitas nelayan perlahan berubah.

Sebagai nelayan wisata, mereka tidak lagi menangkap ikan. Sebaliknya, mereka menemani para wisatawan yang berkunjung. Selain itu, mereka juga memandu wisatawan dalam aktivitas wisata seperti snorkeling. Nelayan mulai belajar mengenal teknologi seperti pengoperasioan smartphone dan kamera profesional. Selain itu, ada perubahan aktivitas di dalam laut. Jika sebelumnya nelayan lebih banyak melakukan aktivitas menembak di dalam laut, kini mereka menyediakan jasa foto dalam air bagi para wisatawan. Meskipun demikian, 
ternyata hanya 30 persen nelayan yang secara kentara mengalami perubahan aktivitas. Hal ini dikarenakan hanya sedikit nelayan yang menyewakan peralatan wisata seperti alat snorkeling dan penginapan. Perubahan aktivitas yang dapat teramati secara langsung adalah perubahan aktivitas pada taraf unit individu, yaitu perubahan dari nelayan tangkap menjadi nelayan wisata berupa tour guide (pemandu wisata).

Perubahan alat tangkap yang teramati adalah perubahan fungsi kapal sebagai alat transportasi wisatawan. Sebanyak 67,5 persen nelayan mengaku menyewakan perahu mereka untuk keperluan wisata. Secara keseluruhan, nelayan yang melakukan perubahan alat tangkap ada 55 persen. Artinya, selain menjadi tour guide mereka juga menjadi nahkoda atas kapal mereka yang disewa untuk aktivitas wisata. Selain mengalami perubahan fungsi, kapal juga mengalami perubahan bentuk serta penambahan alat. Perubahan bentuk yang terjadi adalah adanya tenda di atas geladak kapal. Pemasangan tenda berfungsi untuk melindungi para wisatawan dari sengatan panas matahari. Penambahan alat yang dapat ditemukan di nelayan adalah tangga, baju apung, serta peralatan snorkeling. Tangga digunakan untuk membantu wisatawan ketika akan turun snorkeling. Tangga merupakan salah satu ciri khas yang membedakan nelayan tangkap merangkap wisata dengan nelayan tangkap tanpa pola nafkah lain.

\section{TARAF HIDUP RUMAH TANGGA NELAYAN}

\section{Tingkat Pendapatan}

Tingkat pendapatan rumah tangga nelayan adalah besarnya pendapatan rumah tangga nelayan yang disumbang oleh seluruh anggota keluarga rumah tangga nelayan. Pada penelitian ini, penulis membatasi sumber pendapatan dari sektor nelayan tangkap, nelayan wisata, dan pendapatan lain selain dari pinjaman dan bantuan. Penghitungan total pendapatan tahunan dihitung berdasarkan pendekatan asumsi-asumsi tertentu berdasarkan penghitungan kalender musim nelayan di Karimunjawa.

Sektor pendapatan dari hasil menangkap ikan berasal dari memancing, nembak, bubu, dan jaring gillnet. Mayoritas nelayan (27.5\%) berpenghasilan dibawah Rp 10.000.000,00/tahun. Penghasilan ini dihitung berdasarkan UMK sebesar Rp $800.000,00 /$ bulan atau Rp 9.600.000,00/tahun. Sedangkan nelayan dengan pendapatan lebih dari
$\mathrm{Rp} 40.000 .000,00 /$ tahun ada 35 persen. Sektor wisata menyumbang pendapatan yang cukup signifikan. Rumah tangga nelayan dengan pendapatan lebih dari Rp 40.000.000,00/tahun mencapai 22.5 persen. Pendapatan sektor nelayan yang tinggi ini diperoleh dari pekerjaan sebagai tour guide, nahkoda kapal, menyewakan kapal dan peralatan perlengkapan wisata seperti baju apung dan alat snorkeling, berjualan di sektor wisata, serta bekerja sebagai tenaga kebersihan di resort/hotel dan penginapan/homestay.

Tabel 2 Pendapatan nelayan berdasarkan sumber pendapatan

\begin{tabular}{lcccccc}
\hline Pendapatan Keluarga & \multicolumn{2}{c}{ Tangkap } & \multicolumn{2}{c}{ Wisata } & \multicolumn{3}{c}{ Sektor Lain } \\
$(\mathrm{Rp} /$ tahun $)$ & $\mathrm{n}$ & $\%$ & $\mathrm{n}$ & $\%$ & $\mathrm{n}$ & $\%$ \\
\hline$<10$ juta & 11 & 27.5 & 13 & 32.5 & 29 & 72.5 \\
10 juta $<\mathrm{X} \geq 20$ juta & 5 & 12.5 & 10 & 25 & 6 & 15 \\
20 juta $<\mathrm{X} \geq 30$ juta & 7 & 17.5 & 5 & 12.5 & 1 & 2.5 \\
30 juta $<\mathrm{X} \geq 40$ juta & 3 & 7.5 & 3 & 7.5 & 2 & 5 \\
40 juta $<\mathrm{X} \geq 50$ juta & 4 & 10 & 4 & 10 & 1 & 2.5 \\
50 juta $<X \geq 100$ juta & 7 & 17.5 & 5 & 12.5 & 1 & 2.5 \\
$>100$ juta & 3 & 7.5 & 0 & 0 & 0 & 0 \\
\hline Total & 40 & 100 & 40 & 100 & 40 & 100 \\
\hline
\end{tabular}

Tingkat pendapatan rumah tangga nelayan Karimunjawa mayoritas rendah (37,5\%). Jumlah rumah tangga responden yang memiliki tingkat pendapatan tinggi mencapai 27,5 persen. Meskipun mayoritas berpenghasilan rendah, penghasilan rumah tangga nelayan masih lebih tinggi dari standar upah minimum per tahun Kabupaten Jepara. Tingkat pendapatan rumah tangga nelayan dikatakan rendah jika total pendapatan rumah tangga nelayan kurang atau sama dengan dari Rp 44.040.144,00/tahun. Sedangkan tingkat pendapatan rumah tangga nelayan digolongkan dalam tingkat pendapatan tinggi jika total pendapatan rumah tangga lebih dari atau sama dengan $\mathrm{Rp}$ 94.345.656,00/tahun.

\section{Tingkat Pengeluaran}

Tingkat pengeluaran dapat diukur berdasarkan pengeluaran sektor konsumsi dan pengeluaran sektor non-konsumsi. Dalam penelitian ini, sektor pengeluaran konsumsi dihitung berdasarkan pengeluaran rumah tangga untuk konsumsi harian, seperti sembako dan minyak untuk memasak. Sedangkan sektor pengeluaran non-konsumsi diukur dari pengeluaran rumah tangga untuk pembayaran listrik, air, dan pulsa. Semua hasil pengeluaran 
rumah tangga tersebut dihitung menggunakan pendekatan sederhana dan asumsi-asumsi tertentu sehingga diperoleh pengeluaran tahunan rumah tangga.

Tabel 3 Pengeluaran rumah tangga menurut sektor

\begin{tabular}{lcccc}
\hline $\begin{array}{c}\text { Pengeluaran Keluarga } \\
(\text { Rp/tahun })\end{array}$ & \multicolumn{2}{c}{ Konsumsi } & \multicolumn{2}{c}{$\begin{array}{c}\text { Kon- } \\
\text { Konsumsi }\end{array}$} \\
\hline$<10$ juta & 1 & 2.5 & 40 & 100 \\
10 juta $<X \geq 20$ juta & 22 & 55 & 0 & 0 \\
20 juta $<X \geq 30$ juta & 8 & 20 & 0 & 0 \\
$>30$ juta & 9 & 22.5 & 0 & 0 \\
\hline Total & 40 & 100 & 40 & 100 \\
\hline
\end{tabular}

Jika seluruh sektor pengeluaran ini ditotalkan, terlihat rumah tangga nelayan di Desa Karimunjawa mayoritas memiliki tingkat pengeluaran sedang (35\%). Rumah tangga dengan pengeluaran dibawah atau sama dengan $\mathrm{Rp} 20.461 .847,00 /$ tahun digolongan ke dalam tingkat pengeluaran rendah. Sedangkan rumah tangga dengan pengeluaran di atas atau sama dengan Rp 28.810.753,00/tahun digolongkan ke dalam rumah tangga dengan tingkat pengeluaran tinggi. Rumah tangga dengan pengeluaran diantara itu termasuk dalam tingkat pengeluaran sedang. Semakin tinggi tingkat pengeluaran rumah tangga responden, semakin tinggi pula taraf hidupnya.

\section{Kondisi Sarana Prasarana}

Rumah merupakan salah satu unsur pokok dari kebutuhan dasar selain dari sandang dan pangan. Rumah tidak lagi menjadi tempat tinggal semata, tetapi juga memiliki fungsi sebagai gaya hidup dan simbol yang menunjukan identitas pemiliknya. Kualitas bahan bangunan yang digunakan dapat dijadikan tolak ukur kesejahteraan penghuninya. Selain itu, barang-barang atau fasilitas yang digunakan dalam kehidupan sehari-hari juga dapat menjadi patokan apakah rumah tangga tersebut termasuk dalam rumah tangga sejahtera atau belum.

Secara umum, kepemilikan rumah, bahan bangunan, serta fasilitas yang digunakan dalam rumah atau yang menunjang aktivitas sehari-hari digolongkan dalam kondisi sarana prasarana rumah tangga. Tingkat kondisi sarana prasarana rumah tangga nelayan dapat dilihat dari status kepemilikan rumah, jenis atap penutup bagian atas, jenis lantai, jenis dinding, fasilitas MCK, sumber penerangan, sumber perolehan air minum, jenis bahan bakar, dan kepemilikan barang elektronik dan kendaraan. Diluar dugaan, tingkat kondisi sarana prasarana rumah tangga nelayan Karimunjawa mayoritas tinggi $(52,5 \%)$.

\section{HUBUNGAN PENGEMBANGAN WISATA DAN STRATEGI NAFKAH RUMAH TANGGA NELAYAN}

Variabel pengembangan wilayah dan kegiatan wisata tidak memiliki korelasi dan tidak signifikan terhadap strategi nafkah yang diterapkan oleh keluarga nelayan di Desa Karimunjawa. Artinya, pengetahuan nelayan akan pengembangan wisata yang ada atau sedang dilakukan di Desa Karimunjawa tidak berhubungan dan tidak menentukan dilakukan atau tidak dilakukannya strategi nafkah rumah tangga nelayan di Desa Karimunjawa.

Setidaknya ada dua faktor yang menyebabkan pengetahuan nelayan akan pengembangan wisata tidak berhubungan sama sekali dengan strategi nafkah yang mereka terapkan. Pertama, pengetahuan yang dimiliki nelayan hanya sebatas pengetahuan, sedangkan pengambil keputusan yang berkaitan dengan pengembangan wisata tidak berada pada nelayan. Kedua, nelayan tidak punya kewenangan untuk menentukan arah pengembangan wisata sehingga nelayan tidak terlalu peduli dengan pengembangan wisata yang terjadi.

\section{HUBUNGAN KARAKTERISTIK NELAYAN DENGAN STRATEGI NAFKAH RUMAH TANGGA NELAYAN}

\section{Waktu Kerja dan Strategi Nafkah}

Banyaknya curahan waktu kerja nelayan akan memengaruhi strategi nafkah yang ia terapkan. Nelayan penuh akan mengalokasikan semua waktu kerjanya hanya untuk menangkap ikan tanpa memikirkan sumber nafkah lain. Nelayan sambilan utama menggunakan sebagian besar waktunya untuk menangkap ikan, meskipun demikian, mereka punya sebagian waktu lain untuk dialokasikan pada sektor-sektor sumber nafkah lain selain dari menangkap ikan di laut. Sedangkan nelayan sambilan tambahan tetap mencurahkan waktu kerjanya untuk menangkap ikan, akan tetapi, sebagian besar waktu kerjanya dicurahkan untuk sektor sumber nafkah selain dari menangkap ikan. 
Waktu kerja memiliki korelasi yang cukup kuat dan signifikan dengan perubahan alat tangkap. Semakin banyak nelayan yang menjadi nelayan sambilan tambahan atau semakin sedikit curahan waktu kerja nelayan untuk menangkap ikan, semakin besar perubahan fungsi alat tangkap yang terjadi. Hal ini dikarenakan alokasi waktu kerja nelayan digunakan untuk sektor luar nelayan tangkap. Alokasi waktu kerja tersebut digunakan untuk mengantar wisatawan atau melayani jasa booking wisatawan. Oleh karena hal tersebut, kapal yang mereka pakai dimodifikasi sesuai dengan peraturan keamanan seperti yang diatur oleh kesepakatan bersama.

\section{Kelas Sosial dan Strategi Nafkah}

Kelas sosial memiliki korelasi yang kuat dan nyata dengan perubahan alat tangkap dan optimalisasi tenaga kerja rumah tangga. Kelas sosial yang terbentuk dipengaruhi oleh ukuran kapal yang dimiliki nelayan. Pada umumnya, nelayan dengan kepemilikan kapal dengan kapasitas lebih besar lebih banyak disewa karena dapat menampung lebih banyak wisatawan dalam sekali angkut. Hal ini dapat menyebabkan mobilitas sosial yang tidak seimbang. Golongan nelayan dengan kelas sosial tinggi akan semakin tinggi, sedangkan golongan kelas nelayan rendah akan semakin rendah. Hal ini dikarenakan kesempatan untuk meningkatkan taraf hidup tidak lagi sama.

Mobilitas nelayan sendiri dibagi dua, yaitu mobilitas vertikal dan mobilitas horizontal. Mobilitas vertikal dialami oleh nelayan golongan kelas sosial rendah atau sedang. Golongan kelas sosial rendah atau sedang tidak memiliki kapal yang cukup mumpuni untuk mengangkut wisatawan. kondisi ini disiasati dengan optimalisasi tenaga kerja anggota tumah tangga. Pada kondisi ini, rumah tangga nelayan dapat mengalami dua jenis mobilitas sosial sekaligus, yaitu mobilitas vertikal dan mobilitas horizontal. Mobilitas horizontal terjadi ketika terjadi perpindahan kerja dari nelayan tangkap menjadi nelayan wisata. Akan tetapi, nelayan tanpa kapal tidak dapat menyewakan kapal. Sehingga perpindahan yang terjadi hanya sebatas menjadi pemandu wisata. Pekerjaan ini tidak banyak meningkatkan status sosial nelayan. Akan tetapi, pengoptimalisasian tenaga kerja anggota kerja dapat mendorong terjadinya mobilitas sosial vertikal berupa social climbing.

\section{HUBUNGAN STRATEGI NAFKAH DAN TARAF HIDUP RUMAH TANGGA NELAYAN}

\section{Migrasi dan Taraf Hidup}

Migrasi tidak berkorelasi dengan taraf hidup rumah tangga nelayan. Kondisi ini tidak mengherankan karena tidak banyak nelayan yang melakukan migrasi keluar daerah Karimunjawa. Kebanyakan nelayan di Karimunjawa merupakan penduduk asli. Sebagian besar kerabat atau keluarga juga tinggal di Karimunjawa.

“...mbah SBR kawit mbiyen neng
Karimunjawa om, ora tau merantau. Luweh
penak kumpul karo anak bojo. Sanajan
ngeleh nanging seneng...” (mbah SBR,
Nelayan)
“... mbah SBR dari dulu di Karimunjawa om,
tidak pernah merantau. Lebih enak kumpul
dengan anak istri. Meskipun lapar tapi
bahagia...” (mbah SBR, Nelayan)

Rata-rata nelayan yang melakukan migrasi pada waktu mereka masih bujang atau belum menikah. Ketika sudah berkeluarga dan memiliki anak, nelayan cenderung bertahan di Karimunjawa meskipun terjadi paceklik hasil tangkapan. Bagi sebagian besar nelayan, berkumpul dengan keluarga lebih menyenangkan dibandingkan dengan banyak uang tapi jauh dari keluarga. Faktor ini didukung oleh pernyataan salah satu responden, SBR.

\section{Jejaring Sosial dan Taraf Hidup Rumah Tangga}

Jejaring sosial yang dimiliki oleh nelayan Karimunjawa dapat dilihat berdasarkan dua hal, yaitu informasi dan ikatan kerja. Setidaknya, nelayan Karimunjawa memiliki jejaring dengan lima pihak lain dalam kaitannya dengan aktivitas produktif, baik sebagai nelayan tangkap, nelayan wisata, maupun sektor pekerjaan lain yang menunjang pemenuhan kebutuhan hidup rumah tangga.

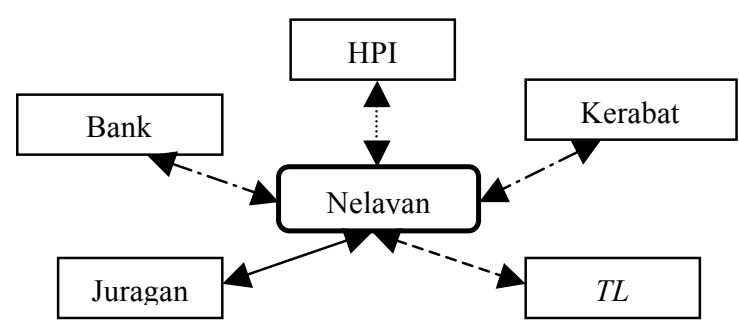

Gambar 4 Pola jejaring sosial nelayan dengan pihak lain 
Macam jejaring sosial nelayan Karimunjawa dapat dijelaskan sebagai berikut:

1. Hubungan yang terikat kesepakatan (ikatan kerja), adalah jenis jejaring sosial nelayan dengan para juragan, atau biasa disebut patron-klien;

2. Hubungan organisasi, adalah jenis jejaring sosial nelayan dengan Himpunan Pramuwisata Indonesia (HPI). HPI adalah organisasi yang menaungi nelayan dalam kaitannya dengan penyelenggaraan wisata di Karimunjawa. Jenis hubungan yang terjadi adalah pertukaran informasi, perlindungan dan kepastian hak dan kewajiban, dan sosialisasi peraturan baru. Sebagai gantinya, tiap bulan nelayan memberikan iuran wajib anggota untuk membiayai jalannya organisasi;

3. Hubungan kerja informatif, yaitu jenis jejaring sosial nelayan dengan tour leader. Bagi nelayan, tour leader memberikan informasi secara berkala mengenai kedatangan wisatawan sekaligus memberikan pekerjaan kepada nelayan wisata, baik sebagai pemandu wisata ataupun sebagai nahkoda kapal. Timbal baliknya, nelayan memberikan keuntungan bagi tour leader melalui paket wisata yang mereka sediakan;

4. Hubungan kerja tanpa ikatan, yaitu jenis jejaring sosial yang dimiliki nelayan dengan kerabat/teman dan bank/koperasi. Kepada kerabat/teman, nelayan biasanya meminjam uang sebatas untuk kebutuhan konsumsi. Sedangkan kepada bank/koperasi, nelayan meminjam uang dalam jumlah besar. Biasanya, uang pinjaman tersebut digunakan untuk sumber permodalan demi menunjang aktivitas produktif guna meningkatkan pendapatan.

\section{Perubahan Alat Tangkap dan Taraf Hidup}

Perubahan alat tangkap memiliki korelasi yang kuat dan nyata dengan variabel tingkat pendapatan dan kondisi sarana prasarana rumah tangga nelayan. Perubahan alat tangkap berhubungan kuat dengan tingkat pendapatan karena secara langsung menentukan kemampuan memaksimalkan sumber nafkah dari sektor wisata.

Sebagai adaptasi dari pengembangan wisata di Karimunjawa dan semakin tingginya permintaan akan wisata, nelayan melakukan modifikasi kapal sekaligus diversifikasi fungsi kapal. Setelah dimodifikasi dengan penambahan tangga dan tenda serta peralatan keamanan seperti baju apung, kapal nelayan tidak lagi hanya berfungsi sebagai alat tangkap. Ada fungsi tambahan yaitu sebagai alat transportasi bagi wisatawan. Modifikasi serta diversifikasi fungsi kapal ini menjadi bagian dari pola nafkah ganda yang diterapkan oleh nelayan.

\section{Optimalisasi Tenaga Kerja dan Taraf Hidup}

Variabel optimalisasi tenaga kerja anggota keluarga dengan variabel tingkat pengeluaran. Akan tetapi, tidak ada korelasi nyata dengan tingkat pendapatan, dan kondisi sarana prasarana rumah tangga nelayan. Peluang untuk memanfaatkan tenaga kerja anggota rumah tangga sebenarnya sangat besar. Akan tetapi, berdasarkan pengamatan penulis dan juga wawancara mendalam dengan beberapa responden, tidak banyak rumah tangga nelayan yang memanfaatkan tenaga kerja anggota rumah tangga. Selain itu, kreativitas anggota rumah tangga masih sangat minim sehingga pemanfaatan sektor informal masih jarang dilakukan. Sektor-sektor informal justru lebih banyak dimanfaatkan oleh pendatang. Istri-istri lebih banyak bergantung kepada suami. Selain itu, anak-anak usia remaja masih ada di rentang usia sekolah sehingga sulit untuk mendorong mereka ikut terjun dalam upaya mencari nafkah. Oleh karena itu, sulit menemukan hubungan antara variabel optimalisasi tenaga kerja anggota rumah tangga dengan taraf hidup rumah tangga nelayan.

\section{SIMPULAN DAN SARAN}

\section{Simpulan}

1. Pengembangan wisata di Desa Karimunjawa tergolong sebagai pariwisata (mass tourism), bukan ekowisata (ecotourism). Penawaran jasa dan jumlah kunjungan yang meningkat pesat menjadi faktor utama kecenderungan wisata Karimunjawa sebagai industri.

2. Sebagian besar nelayan Karimunjawa termasuk dalam golongan nelayan sambilan utama, yaitu nelayan dengan pekerjaan utama menangkap ikan namun mengalokasikan sebagian waktunya untuk pekerjaan lain. Pekerjaan sampingan mayoritas adalah sebagai nelayan wisata.

3. Jejaring sosial, perubahan aktivitas, dan perubahan fungsi kapal merupakan aklternatif strategi nafkah mayoritas yang diterapkan oleh nelayan Karimunjawa. Pilihan strategi nafkah ini dipengaruhi oleh karakteristik nelayan berdasarkan kelas sosial dan waktu kerja. 
4. Pengetahuan nelayan akan pengembangan wisata tidak memengaruhi strategi nafkah yang diterapkan rumah tangga nelayan.

5. Tingkat pendapatan rumah tangga nelayan memperlihatkan adanya hubungan yang sangat kuat dengan strategi nafkah, terutama pola nafkah ganda dan optimalisasi tenaga kerja anggota rumah tangga. Sektor wisata dapat menjadi alternatif yang cukup menjanjikan ketika hasil tangkapan semakin menurun dari tahun ke tahun.

\section{Saran}

1. Dorong diversifikasi nelayan tangkap menjadi nelayan wisata.

2. Tingkatkan perubahan fungsi alat tangkap dan cara adaptasi nelayan di bidang wisata.

3. Memperkuat jejaring sosial lintas sektoral

\section{DAFTAR PUSTAKA}

Amanah S dan Utami HN. 2006. Aktivitas nelayan dalam pengelolaan bahari di kawasan pantai Lovina, Buleleng, Bali. Jurnal Penyuluhan. [Internet]. [dikutip tanggal 26 Novemmber 2014]; 2:83-90. Dapat diunduh di http://repository.ipbac.id/handle/123456789/43022.

[BPS] Badan Pusat Statistik. 2014. Penerimaan dari wisatawan mancanegara menurut negara tempat tinggal (juta US\$) tahun 2000-2013. [internet]. Diunduh pada 17 Januari 2015. Dapat diunduh di http://bps.go.id/linkTabelStatis-/view/id/1392.

[BTNKJ] Balai Taman Nasional Karimunjawa. 2012. Statistik Balai Taman Nasional Karimunjawa 2012. Semarang: Kementrian Kehutanan RI.

Dharmawan AH. 2007. Sistem Penghidupan dan Nafkah Pedesaan. [Internet]. [dikutip tangal 17 Febuari 2015]. Sodality: Transdisiplin Sosiologi,

Komunikasi, dan Ekologi Manusia ISSN: 1978-4333, 01(02). Dapat diunduh dari: http://journal-

.ipb.ac.id/index.php/sodality/article/.../4609.

Ellis. 2000. Rural Livelihoods and Diversity in Developing Countries. New York (US). Oxford Unversity Press.
Eplerwood M. 1999. Ecotourism, sustainable development, and cultural survival: protecting indegeneous culture and through ecotourism. Cultural Survival Quarterly. [Internet]. [Dikutip pada 6 Desember 2014]; 23(2). Dapat diunduh di http://209.200.101.189/publications/csq/csq article.cfm?id=1431\&highlight $=$ ecotourism.

Esmara H. 2004. Kemiskinan dan Kebutuhan Pokok. Jakarta: CV Rajawali.

Helmi A, Satria A. 2012. Strategi adaptasi nelayan terhadap perubahan ekologis. Makara, Sosial Humaniora. [Internet]. [dikutip 26 November 2014]; 16:68-78. Dapat diunduh di http://journa1.ui.ac.id/index.php/humanities/article/view/ 1494

Istiqlaliah M. 2010. Analisis dan pengembangan model peningkatan kualitas sumber daya manusia dan kesejahteraan keluarga di wilayah pesisir provinsi Jawa Barat. Bogor: Sekolah Pascasarjana IPB.

Kinseng RA. 2011. Konflik kelas nelayan di Indonesia tinjauan kasus Balikpapan. Bogor: IPB Press.

Kusnadi. 2009. Keberdayaan nelayan dan dinamika ekonomi pesisir. Yogyakarta: Lembaga Penelitian Universitas Jember dan Ar-Ruzz Media.

Manullang M. 2011. Aktivitas organisasi. Jakarta: Usaha Nasional.

Mathieson A, Wall G. 1982. Tourism: economic, physical and social impacts. Longman [UK]: Harlow.

Pitana IG dan Gayatri PG. 2005. Sosiologi Pariwisata. Yogyakarta [ID]: Penerbit ANDI.

Satria A. 2002. Pengantar Sosiologi Masyarakat Pesisir. Jakarta [ID]: Cidesindo. 2009. Pesisir dan Laut untuk Rakyat. Bogor [ID]: IPBPress.

Satria A, Matsuda Y. 2004. Decentralization of fisheries management in Indonesia. Marine Policy. [Internet]. [dikutip 30 Oktober 2014]; 28(5):437-450. Dapat diunduh di: http://www.sciencedirect.com/science/article/pii/S0-308597X0300-1362.

Satria A, Matsuda Y, Masaaki Sano. 2005. Contractual solution to the tragedy of property right in coastal fisheries. Marine Policy. [Internet]. [dikutip 30 Oktober 2014]; 30:226-236. Dapat diunduh dari http://www.sciencedirect.com/science/articl-/pii/-S0308597X-05000126.

Setyadi IA, Hartoyo, Maulana A, Muntasib H. 2012. Strategi pengembangan ekowisata di taman nasional Sebangau Kalimantan Tengah. Jurnal 
Manajemen\&Agribisnis. [Internet]. [Dikutip pada 5 Desember 2014]; 09(1):1-12. Dapat diunduh di http://repository.mb.ipb.ac.id/1557/.

Sobari MP, Kinseng RA, dan Priyatna FN. 2003. Membangun model pengelolaan sumberdaya perikanan berkelanjutan berdasarkan karaktersitik sosial ekonomi masyarakat nelayan: tinjauan sosiologi antropologi. Buletin Ekonomi Perikanan: 5(1). [internet]. [diunduh pada 13 Januari 2015]. Dapat diunduh di http://reposi-

tory.ipb.ac.id/bitstream/handle/123456789/4362 2/Moch.\%20Prihatna $\% 20$ Sobari.pdf?sequence= 1 .

Tafalas M. 2010. Dampak pengembangan ekowisata terhadap kehidupan sosial dan ekonomi masyarakat lokal. Studi kasus ekowisata bahari pulau Mansuar Kabupaten Raja Ampat. [Thesis]. [Internet]. [dikutip tanggal 10 Desember 2014]. Bogor: Sekolah Pascasarjana IPB. Dapat diunduh di http://repository.ipb.ac.id/bitstream/handle/123456789/41156/2010 mta.pdf?sequence $=10$.

Yoeti OA. 2000. Ekowisata, pariwisata berwawasan lingkungan hidup. Jakarta: PT Pertja.

Yulianda F. 2007. Ekowisata bahari sebagai alternatif pemanfaatan sumberdaya pesisir berbasis konservasi. Makalah Seminar Sains pada Departemen Manajemen Sumberdaya Perairan. Fakultas Perikanan dan Ilmu Kelautan. Bogor: Institut Pertanian Bogor. 